\title{
ANALISIS PENGARUH PAPARAN FISIK PADA SAMPEL GIGI TERHADAP HASIL KUANTIFIKASI DNA FORENSIK MENGGUNAKAN METODE KIT PURIFIKASI DNA KOMERSIAL
}

\author{
Septi Arini, S.Biotek ${ }^{1}$, Dr. Arief Budi Witarto, M.Eng ${ }^{2}$, Setia Betaria Aritonang, M.Si ${ }^{3}$ \\ $1^{*}$ Sekolah Pascasarjana Manajemen Inovasi Universitas Teknologi Sumbawa \\ ${ }^{2}$ Sekolah Pascasarjana Manajemen Inovasi Universitas Teknologi Sumbawa \\ ${ }^{3}$ Pusat Laboratorium Forensik Badan Reserse Kriminal Polri (PUSLABFOR BARESKRIM POLRI), Jakarta.
}

*Corresponding Author email: ${ }^{1}$ septi020ftbuts@gmail.com, ${ }^{2}$ Witarto@gmail.com, setiabetaria@yahoo.com³

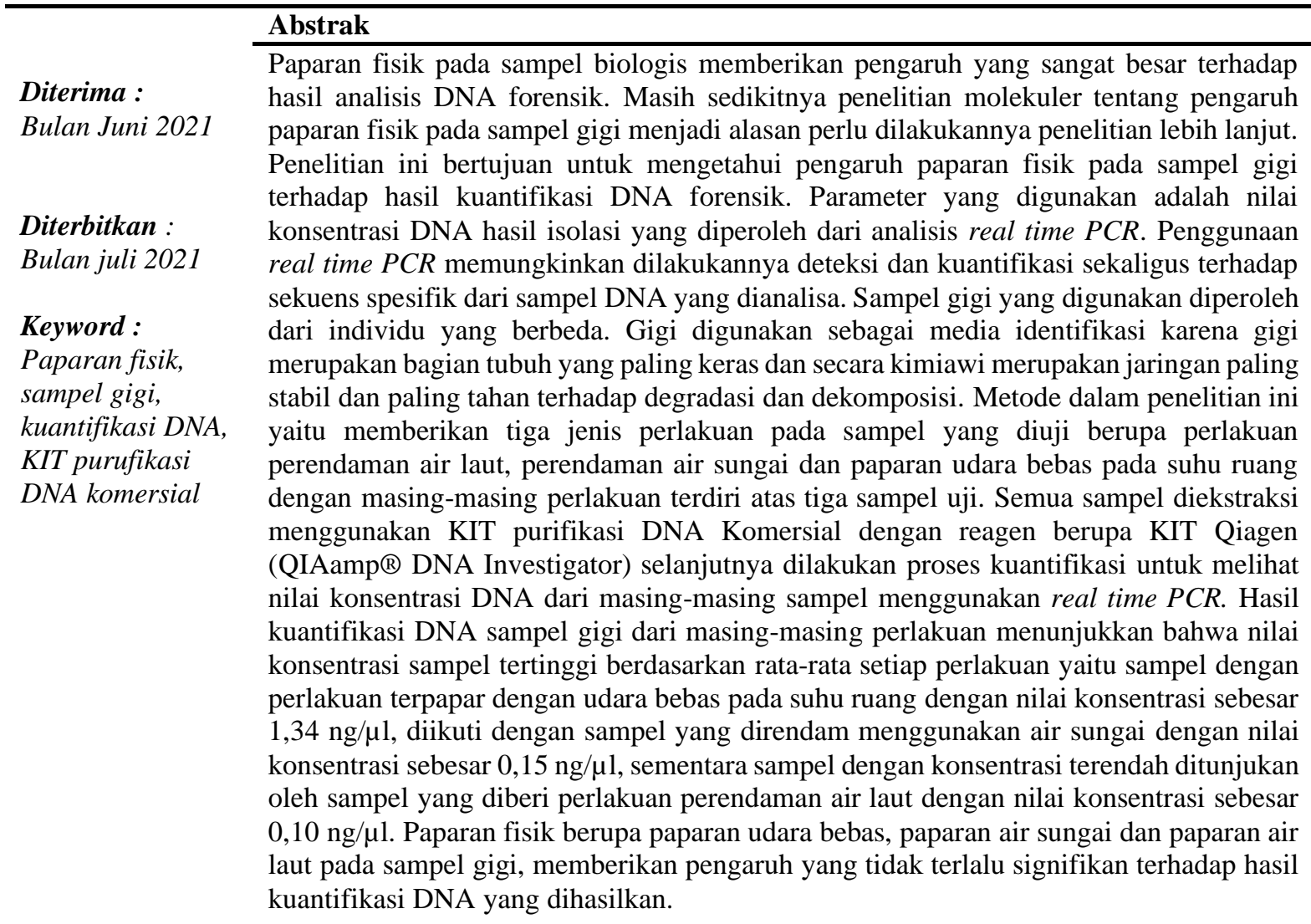

\section{PENDAHULUAN}

Indonesia terdapat banyak kasus kriminal yang terjadi, mulai dari terorisme, pembunuhan, pencurian ataupun tindak pemerkosaan. Seiring dengan banyaknya kasus, mengidentifikasi pelaku atau korban dan menentukan waktu terjadinya kejadian selalu menjadi masalah yang sulit untuk diselesaikan oleh pihak berwajib. Barang bukti biologis yang paling umum ditemukan dalam kasus kriminal adalah cairan tubuh yang dapat berupa darah, sperma, saliva, tulang, puntung rokok, dan semua bagian tubuh manusia yang dapat dijadikan petunjuk dalam pemeriksaan DNA forensik. Identifikasi atau pengenalan identitas seseorang pada awalnya berkembang untuk kebutuhan dalam proses penyidikan suatu tindak pidana khususnya penyelesaian permasalahan kriminal, namun seiring dengan perkembangan ilmu pengetahuan dan teknologi, serta terjadinya peningkatan masalah sosial, menjadikan proses identifikasi digunakan dalam berbagai penyelesaian kasus baik yang terjadi di darat, laut, maupun udara. Kasus-kasus seperti ini, tidak jarang dialami kesulitan dalam melakukan identifikasi korban karena kerusakan akan membuat sulit untuk mengenali jenazah. Proses identifikasi menjadi salah satu unsur penting tidak hanya untuk mengetahui penyebab kematian tetapi juga sebahai salah satu upaya memberikan ketenangan psikologis kepada keluarga (Syafitri et al., 2013).

Identifikasi individu dapat dilakukan melalui beberapa parameter, yaitu identifikasi usia, ras, jenis kelamin dan identifikasi profil DNA. Identifikasi jenis kelamin, usia dan ras dapat dilakukan ketika korban berada dalam kondisi yang mana jenazah masih bisa dilihat dengan jelas dari 
karakteristik fisiknya. Sementara, apabila korban mengalami kecelakaan fatal yang mengakibatkan rusaknya sebagian besar organ tubuhnya, maka pemeriksaan yang dapat digunakan untuk mengetahui identitas dari korban ialah melalui analisis DNA. Salah satu bagian tubuh yang memiliki kandungan DNA yang cukup tinggi, meskipun bagian tubuh lain telah mengalami denaturasi DNA karena faktor-faktor tertentu, adalah gigi (Syafitri et al., 2013). Sebagai media identifikasi gigi dipilih karena gigi merupakan jaringan tubuh yang paling keras dan secara kimiawi tahan terhadap degradasi dan dekomposisi, dengan demikian gigi dapat bertahan untuk periode yang lama dibandingkan dengan jaringan tubuh lainnya (Higgins \& Austin, 2013). Gigi juga memiliki ketahanan terhadap temperatur yang tinggi sehingga sangat bermanfaat dalam identifikasi pada korban terbakar (Febri et al., 2013).

Paparan fisik setiap sampel gigi tentunya berbeda, tergantung dari lokasi ditemukannya gigi tersebut dan perawatan dari gigi itu sendiri. Penelitian molekuler tentang pengaruh paparan fisik masih sedikit pada sampel gigi, ini menjadi alasan perlu dilakukannya penelitian lebih lanjut menyangkut pengaruh paparan fisik pada sampel gigi terhadap hasil kuantifikasi DNA forensik, dengan indikator utama berupa nilai kemurnian DNA dan kualitas DNA melalui visualisasi DNA hasil isolasi menggunakan real time PCR. Real Time PCR memungkinkan dilakukannya deteksi dan kuantifikasi sekaligus terhadap sekuens spesifik dari sampel DNA yang dianalisa (Bio-Rad Laboratories, 2017).

\section{LANDASAN TEORI}

\section{Deoxyribonucleic Acid (DNA)}

Dewasa ini dengan kemajuan teknologi DNA dalam ilmu forensik disediakan berbagai sarana dalam identifikasi korban dan tersangka dalan suatu kasus kriminalitas termasuk penetuan hubungan keluarga. Berbagai cara klasik telah digunakan sebelumnya seperti visualisasi sidik jari, antigen golongan darah, perbandingan dengan status gigi geligi lain-lain. Perkembangan akhirakhir ini dalam identifikasi genotip memungkinkan penggunaan analisis DNA untuk tujuan identifikasi. Dewasa ini terdapat kecenderungan peningkatan penggunaan analisis DNA dalam bidang forensik, walaupun penggunaannya belum secara luas. Hal ini karena teknik tersebut relatif masih baru dan metode analisa dan aplikasinya harus menurut prosedur standar internasional.

Deoxyribonucleic Acid (DNA) merupakan asam nukleat yang membawa informasi genetik dari setiap individu yang diturunkan dari generasi ke generasi berikutnya. DNA terdapat pada semua jaringan tubuh kecuali sel darah merah karena tidak memiliki inti sel (nukleus) (Butler, 2010). Letak DNA sangat beragam yaitu ada yang terletak pada nukleus, mitokondria pada hewan dan terdapat juga pada kloroplas tumbuhan. Perbedaan antara DNA tersebut, yaitu: DNA nukleus atau sering disebut dengan DNA kromosomal memiliki betuk benang lurus (linear) dan tidak bercabang serta berasosiasi sangat erat dengan protein histon, sedangkan DNA mitokondria dan kloroplasmemiliki bentuk yang melingkar (sirkular) dan tidak berasosiasi dengan protein histon (Hidayat, 2015).

\section{Gigi Sebagai Sumber DNA}

Gigi merupakan salah satu bukti biologis sumber DNA dalam mengidentifikasi kasus forensik ketika sebagian besar organ yang ada dalam tubuh mengalami degradasi (Higgins \& Austin, 2013). Deoxyribonucleic acid (DNA) yang diisolasi dari gigi memiliki kualitas yang lebih tinggi disebabkan karena posisi DNA nya dilindungi dari kondisi lingkungan dan paparan fisik yang dapat mempercepat proses dekomposisi atau pembusukan DNA (Mayall et al., 2013). Gigi adalah jaringan yang paling keras dalam tubuh manusia karena dibalut oleh enamel, yang membuat mereka tahan terhadap kondisi buruk yang dapat merusak DNA, seperti kelembaban, suhu tinggi, dan aktivitas dari jamur dan bakteri (Malaver \& Yunis, 2013).

\section{Distribusi DNA dalam Gigi}

Protokol pengambilan sampel gigi yang optimal memerlukan pemahaman yang komprehensif menyangkut morfologi gigi dan distribusi DNA di dalam gigi. Pemahaman ini memungkinkan pemilihan sampel gigi yang optimal. Secara alamiah, gigi manusia dibagi menjadi dua bagian yaitu mahkota yang timbul di mulut dan akar yang terbungkus oleh gusi.

Gigi merupakan salah satu bukti biologis sumber DNA dalam mengidentifikasi kasus forensik ketika sebagian besar organ yang ada dalam tubuh mengalami degradasi (Higgins \& Austin, 2013). Deoxyribonucleic acid (DNA) yang diisolasi dari gigi memiliki kualitas yang lebih tinggi disebabkan karena posisi DNA nya dilindungi dari kondisi lingkungan dan paparan fisik yang dapat mempercepat proses dekomposisi atau pembusukan DNA (Mayall et al.,2013). Gigi adalah jaringan yang paling keras dalam tubuh manusia karena dibalut oleh enamel, yang membuat mereka tahan terhadap kondisi buruk yang dapat merusak DNA, seperti kelembaban, suhu tinggi, dan aktivitas dari jamur dan bakteri (Malaver \& Yunis, 2013).

\section{Post-Mortem Degradasi}

Degradasi DNA pada gigi tergantung pada waktu tetapi hubungan antara waktu dan degradasi 
sangat dipengaruhi oleh faktor lingkungan (Higgins \& Austin, 2013). Degradasi DNA dalam periode pasca-mortem dimulai dengan pelepasan enzim intraseluler endogen (misalnya lipase, nuklease, dan protease), dan dilanjutkan oleh enzim eksogen yang dihasilkan oleh mikroorganisme dan invertebrata lingkungan (Higgins \& Austin, 2013).

\section{Isolasi DNA dari Sampel Gigi}

Analisa DNA diawali dengan proses ekstraksi DNA. Adapun Tahapan ekstraksi DNA meliputi isolasi dari jaringan, pelisisan dinding dan membran sel, ekstraksi, purifikasi serta presipitasi pemadatan. Ekstraksi DNA dapat dilakukan dengan menggunakan berbagai metode, seperti: metode fenol-kloroform, metode membran dialisis, metode chelex, dll (Jehuda, 2013). Metode ekstraksi fenol-kloroform yang diperkenalkan oleh Sambrook dan Russell adalah Metode ekstraksi yang paling umum digunakan. Metode ini memanfaatkan reagen berupa fenol dan kloroform (Sambrook \& Russel, 2001).

Metode ekstraksi organik dengan menggunakan reagen chelex $20 \%$ menggunakan suspensi resin pengikat ion yang langsung dicampurkan ke dalam sampel. Larutan difmil benzena yang mengandung ion imino diasetat yang dapat mengikat ion-ion metal adalah merupakan suspensi resin yang terdapat dalam chelex. Suspensi tersebut seperti magnesium yang dapat mengikat magnesium. Penggunaan chelex membuat enzim penghancur DNA tidak aktif sehingga molekul DNA akan tetap terlindungi (Butler \& Hill., 2012).

Metode ekstraksi yang digunakan dalam penelitian ini ialah metode ekstraksi kit purifikasi DNA komersial dengan menggunakan reagen berupa kit Qiagen (QIAamp® DNA Investigator) untuk mengisolasi DNA dari sampel gigi. Metode kit purifikasi DNA komersial dengan menggunakan reagen berupa kit Qiagen (QIAamp® DNA Investigator) merupakan metode yang digunakan untuk mendapatkan DNA dari suatu sampel serta mampu mengoptimalkan aktivitas pengikatan dan elusi DNA dari sampel dengan jumlah DNA yang relatif terbatas (QIAamp DNA Investigator Handbook, 2012)

\section{Pengukuran Konsentrasi DNA dengan Real Time PCR}

Real-time PCR merupakan modifikasi dari metode PCR konvensional. Prinsip kerjanya hampir sama dengan PCR konvensional, namun real-time $\mathrm{PCR}$ dapat mengkuantifikasi dan memonitor secara langsung amplifikasi dari
suatuDNA spesifik (Tooy et al., 2016). Adanya zat flourescent reporter memungkinkan terjadinya pemantauan terhadap proses amplifikasi DNA dalam instrumen real-time PCR. Flourescent reporter merupakan zat yang berikatan dengan DNA target dan memancarkan sinyal flourosensi yang menggambarkan jumlah produk yang dihasilkan (Tooy et al., 2016).

\section{METODE}

\section{Waktu dan Lokasi Penelitian}

Penelitian ini dilaksanakan mulai tanggal 23 Maret 2017 sampai 23 Mei 2017 dengan jam kerja selama 7-8 jam dan waktu kerja pukul 07.00-15.00 WIB. Penelitian ini dilaksanakan di Laboratorium Biologi Forensik dan Instalasi Uji Bio Molekuler Forensik, Pusat Laboratorium Forensik Bareskrim Polri Jakarta.

\section{Teknik Pengambilan dan Persiapan Sampel} Sampel gigi yang digunakan dalam penelitian diperoleh dari dokter gigi yang bertugas di daerah Jakarta Timur. Sampel yang digunakan berasal dari individu yang berbeda dan jumlah sampel keseluruhan sebanyak 9 buah. Setiap sampel diberikan perlakuan yang berbeda-beda, ada sampel yang direndam air laut, air sungai, dan ada sampel yang dibiarkan terpapar dengan udara bebas pada suhu ruang. Penelitian ini dilaksanakan di Laboratorium Biologi Forensik dan Instalasi Uji Bio Molekuler Forensik, Pusat Laboratorium Forensik Bareskrim Polri Jakarta.

\section{Analisis Data}

Penelitian ini menggunakan Rancangan Acak Lengkap (RAL) dengan jumlah sampel yang digunakan sebanyak 9 sampel. Data yang diperoleh diolah menggunakan program SPSS versi 16 dan dianalisis dengan menggunakan uji ANOVA serta penyajian data dilakukan dengan tubulating, yaitu dengan menggunakan tabel.

Ada tiga perlakuan yang diberikan dalam penelitian ini, setiap perlakuan masing-masing menggunakan tiga sampel tanpa pengulangan pada proses ekstraksi Kit Purifikasi DNA Komersial dengan menggunakan reagen KIT Qiagen (QIAamp®

DNA Investigator). Perlakuan yang diberikan adalah sebagai berikut :

$\mathrm{C} 1$ = Sampel gigi udara bebas yang disimpan pada suhu ruang

$\mathrm{C} 2=$ Sampel gigi udara bebas yang disimpan pada suhu ruang

C3 = Sampel gigi udara bebas yang disimpan pada suhu ruang

AS1 = Sampel perlakuan yang direndam dengan air sungai selama 2 kali 24 jam

AS2 = Sampel perlakuan yang direndam 
dengan air sungai selama 2 kali 24 jam

AS3 = Sampel perlakuan yang direndam dengan air sungai selama 2 kali 24 jam

AL1 = Sampel perlakuan yang direndam dengan air laut selama 2 kali 24 jam

AL2 = Sampel perlakuan yang direndam dengan air laut selama 2 kali 24 jam

AL3 = Sampel perlakuan yang direndam dengan air laut selama 2 kali 24 jam

\section{Gambaran Penelitian}

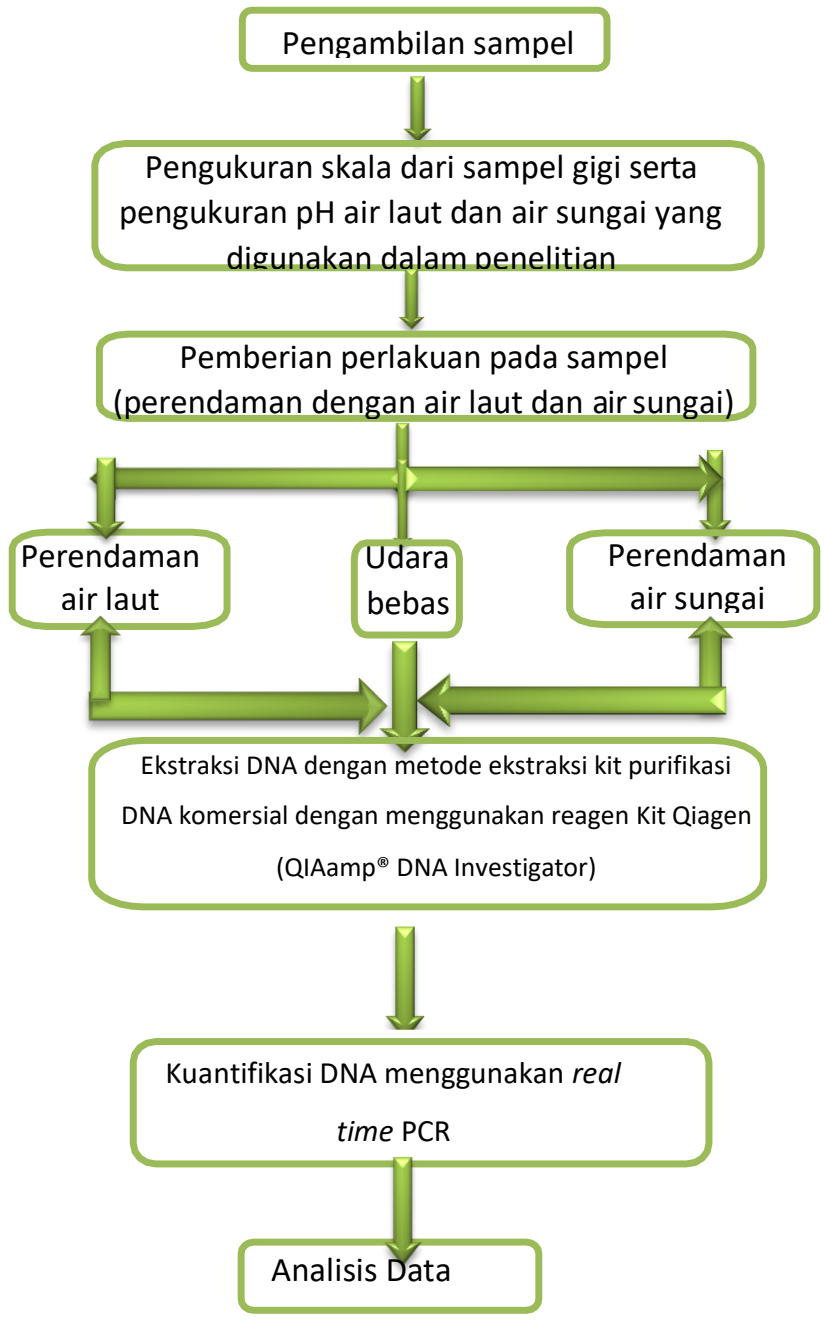

Data yang telah diperoleh dalam penelitian ini selanjutnya diuji hubungan antar variabelnya menggunakan uji statistik dengan Uji ANOVA. Uji ANOVA digunakan dalam melihat perbedaan konsentrasi antar sampel berdasarkan perbedaan perlakuan yang diberikan yaitu paparan udara bebas pada suhu ruang, perendaman air laut dan perendaman air sungai. Dalam penelitian ini tidak dilakukan uji lanjut disebabkan karena masing-masing sampel tidak terdapat hubungan yang signifikan jika dilihat dari nilai error bar yang diperoleh.
HASIL

Analisa DNA diawali dengan proses ekstraksi DNA. Ekstraksi DNA secara umum memiliki tahapan-tahapan yang meliputi isolasi dari jaringan, pelisisan dinding dan membran sel, ekstraksi dalam larutan, purifikasi serta presipitasi atau pemadatan. Ekstraksi DNA dapat dilakukan dengan menggunakan berbagai metode, seperti: metode fenol-kloroform, metode membran dialisis, metode chelex, dll (Jehuda, 2013). Salah satu metode ekstraksi yang sering digunakan adalah metode fenol-kloroform yang diperkenalkan oleh Sambrook dan Russell. Metode ini memanfaatkan reagen berupa fenol dan kloroform (Sambrook \& Russel, 2001).

Metode ekstraksi organik dengan menggunakan reagen chelex 20\% menggunakan suspensi resin pengikat ion yang langsung dicampurkan ke dalam sampel. Suspensi resin yang terdapat dalam chelex berupa larutan difmil benzena yang mengandung ion imino diasetat yang dapat mengikat ion-ion metal. Suspensi tersebut seperti magnesium yang dapat mengikat magnesium. Penggunaan chelex membuat enzim penghancur DNA tidak aktif sehingga molekul DNA akan tetap terlindungi (Butler \& Hill., 2012).

Metode ekstraksi yang digunakan dalam penelitian ini ialah metode ekstraksi kit purifikasi DNA komersial dengan menggunakan reagen berupa kit Qiagen (QIAamp® DNA Investigator) untuk mengisolasi DNA dari sampel gigi. Metode kit purifikasi DNA komersial dengan menggunakan reagen berupa kit Qiagen (QIAamp® DNA Investigator) merupakan metode yang digunakan untuk mendapatkan DNA dari suatu sampel serta mampu mengoptimalkan aktivitas pengikatan dan elusi DNA dari sampel dengan jumlah DNA yang relatif terbatas (QIAamp DNA Investigator Handbook, 2012).

Kuantifikasi DNA dari sampel gigi dilakukan menggunakan alat berupa real time PCR. Nilai rata-rata konsentrasi DNA dari masing-masing sampel yang digunakan dalam penelitian disajikan dalam grafik sebagai berikut:

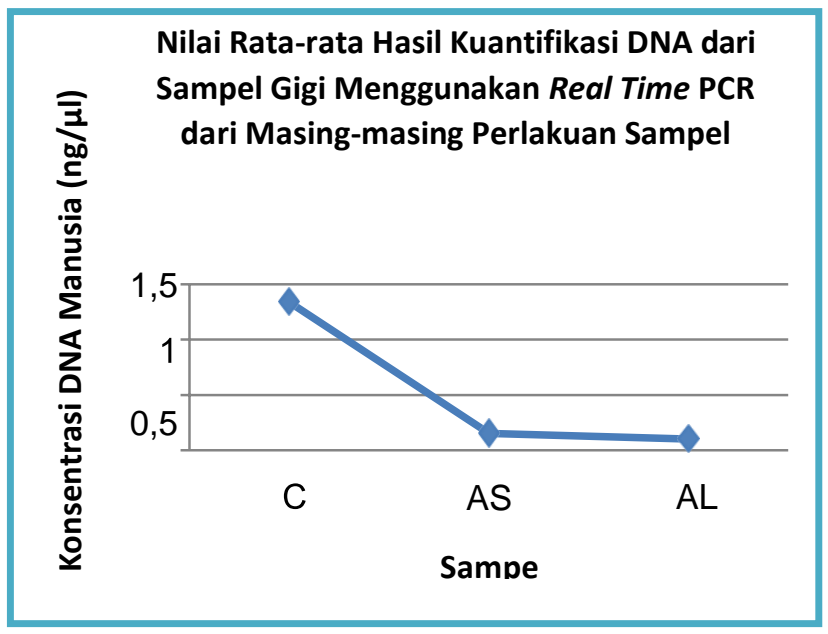


Grafik 1. Nilai rata-rata hasil kuantifikasi DNA dari sampel gigi menggunakan real time PCR dari masing-masing perlakuan sampel.

Keterangan:

$\mathrm{C}=$ Sampel gigi udara bebas yang disimpan pada suhu ruang

$\mathrm{AS}=$ Sampel perlakuan yang

direndam dengan air sungai

selama 2 kali 24 jam

$\mathrm{AL}=$ Sampel perlakuan yang

direndam dengan air laut selama

2 kali 24 jam

Grafik 1. menunjukkan nilai rata-rata konsentrasi dari masing-masing perlakuan sampel. Nilai konsentrasi sampel tertinggi berdasarkan ratarata setiap perlakuan yaitu sampel dengan perlakuan terpapar dengan udara bebas pada suhu ruang dengan nilai konsentrasi sebesar 1,34 ng/ $\mu \mathrm{l}$, dilanjutkan dengan sampel yang direndam menggunakan air sungai dengan nilai konsentrasi sebesar $0,15 \mathrm{ng} / \mu \mathrm{l}$, sementara sampel dengan konsentrasi terendah ditunjukan oleh sampel yang diberi perlakuan perendaman air laut dengan nilai konsentrasi sebesar $0,10 \mathrm{ng} / \mu \mathrm{l}$.

\section{PEMBAHASAN}

\section{Pengambilan Sampel}

Sampel gigi yang digunakan dalam penelitian diperoleh dari seorang dokter gigi yang bertugas di daerah Jakarta Timur. Sampel yang digunakan berasal dari individu yang berbeda. Jumlah sampel yang digunakan ada sembilan buah sampel. Seluruh sampel merupakan sampel gigi stok yang disimpan oleh dokter gigi yang bertugas dengan penyimpanan sesuai prosedur penyimpanan sampel. Sementara sampel air laut dan air sungai yang digunakan sebagai media perendaman sampel gigi diperoleh dari Ancol dengan lokasi yang berbeda.

Gigi digunakan sebagai media identifikasi dalam penelitian ini karena gigi merupakan bagian tubuh yang paling keras dan secara kimiawi merupakan jaringan paling stabil dan paling tahan terhadap degradasi dan dekomposisi, sehingga membuat gigi dapat bertahan untuk periode yang lama dibandingkan dengan jaringan tubuh lainnya (Higgins \& Austin, 2013).

\section{Pengukuran Skala dari Sampel Gigi Serta Pengukuran pH Air Laut dan Air Sungai yang Digunakan dalam Penelitian.}

Pengukuran skala dari sampel gigi bertujuan untuk mengetahui ukuran dari sampel gigi yang digunakan. Mekanisme dalam pengukuran skala dari sampel gigi yaitu semua jenis gigi di ukur panjang dan lebarnya menggunakan jangka sorong kemudian dicatat di buku penelitian. Sementara pengukuran $\mathrm{pH}$ air laut dan air sungai bertujuan untuk mengetaui nilai $\mathrm{pH}$ dari kedua jenis air yang akan digunakan dalam proses pemberian perlakuan pada sampel. Mekanisme pengukuran $\mathrm{pH}$ yaitu air laut dan air sungai di ukur pH-nya menggunakan kertas $\mathrm{pH}$ kemudian dicatat di buku penelitian. Nilai $\mathrm{pH}$ dari air laut dan air sungai yang digunakan dalam penelitian adalah berbeda-beda yakni $\mathrm{pH}$ air sungai sebesar 5 dan $\mathrm{pH}$ air laut sebesar 6 .

Menurut Latif (2012), menyatakan bahwa demineralisasi dapat terjadi apabila email berada dalam suatu lingkungan $\mathrm{pH}$ di bawah 6,5 (pH asam), sedangkan pada kenaikan $\mathrm{pH}$ hingga melebihi batas normal dapat menyebabkan suasana basa dan meningkatkan pembentukan karang gigi yang mengakibatkan larutnya mineral-mineral penyusun struktur gigi. Demineralisasi gigi dipengaruhi oleh peran $\mathrm{pH}$ sebab konsentrasi ion hidrogen akan meningkat dan ion ini akan merusak hidroksiapatit email gigi sedangkan $\mathrm{pH}$ yang tinggi juga akan berakibat pada pelarutan mineral-mineral penyusun tahapan penting dalam proses analisis DNA. Hal ini akan menjadi acuan untuk melihat kemurnian hasil ekstraksi dan dasar perhitungan untuk proses selanjutnya. Kuantifikasi DNA dengan real-time PCR jauh lebih spesifik terhadap DNA target sehingga dapat menentukan kandungan DNA target. Hasil kuantifikasi sampel DNA pada penelitian ini meliputi konsentrasi DNA manusia, DNA laki-laki (male DNA) dan nilai Ct Internal Positive Control (IPC).

\section{Analisis Data dan Pengaruh Paparan Fisik Terhadap Hasil Kuantifikasi DNA dari Sampel Gigi}

Berdasarkan hasil penelitian yang telah dilakukan menunjuk kan bahwa sampel dengan nilai konsentrasi DNA tertinggi ialah sampel yang diberi paparan udara bebas pada suhu ruang dengan nilai konsentrasi sebesar 1,34 ng/ $\mu \mathrm{l}$, dilanjutkan dengan sampel yang direndam menggunakan air sungai dengan nilai konsentrasi sebesar $0,15 \mathrm{ng} / \mu \mathrm{l}$, sementara sampel dengan konsentrasi terendah ditunjukan oleh sampel yang diberi perlakuan perendaman air laut dengan nilai konsentrasi sebesar $0,10 \mathrm{ng} / \mu \mathrm{l}$. Prawestiningtyas \& Algozi (2009), menyatakan bahwa semakin lama sampel gigi terpapar dalam air maka proses pembusukan juga akan berlangsung dengan cepat sehingga akan menyebabkan terbatasnya upaya pemeriksaan primer dan sekunder dan hal ini juga akan berpengaruh terhadap kondisi DNA yang ada dalam sampel.

Degradasi DNA pada gigi tergantung pada waktu tetapi hubungan antara waktu dan degradasi sangat dipengaruhi oleh faktor lingkungan (Higgins \& Austin, 2013). Lingkungan yang kering akan mendorong pengeringan pulpa dan melindungi DNA dari kerusakan hidrolitik tetapi lingkungan yang basah akan memungkinkan pembusukan dan 
penghancuran pulpa (Higgins \& Austin, 2013).

Konsentrasi DNA tertinggi terletak pada perlakuan paparan udara bebas pada suhu ruang disebabkan karena sampel tidak berada di bawah $\mathrm{pH}$ kritis yang mengakibatkan terjadinya demineralisasi email. Sedangkan pada perlakuan perendaman dengan air sungai dan air laut, konsentrasi DNA yang didapatkan relatif kecil disebabkan karena air laut dan air sungai mempunyai pengaruh terhadap sampel gigi. Keduanya mempunyai tingkat keasaman yang hampir sama. $\mathrm{pH}$ air laut yang digunakan dalam penelitian ini yakni 6 sedangkan $\mathrm{pH}$ air sungai yang digunakan ialah 5. Hal ini dapat diartikan bahwa $\mathrm{pH}$ dari keduanya berada di bawah batas $\mathrm{pH}$ kritis. Penelitian menunjukkan bahwa nilai pH 6,5 merupakan pH kritis yang menyebabkan email mengalami proses demineralisasi. Selain itu, kandungan mineral kalsium hidroksiapatit juga akan melarut pada $\mathrm{pH}$ tersebut yang mengakibatkan terjadinya demineralisasi email. Demineralisasi email akan berpengaruh terhadap kestabilan jaringan pulpa yang ada dibawahnya yang mengakibatkan adanya pengaruh terhadap kadar DNA yang ada pada sampel. struktur gigi.

Adanya perbedaan kadar DNA dalam penelitian ini menunjukkan adanya pengaruh paparan fisik berupa udara bebas pada suhu ruang, air sungai dan air laut yang dimungkinkan karena terjadinya proses demineralisasi email yang berakibat pada larutnya berbagai mineral, utamanya kalsium dan fosfat, dengan demikian akan mengganggu kestabilan DNA yang ada didalam gigi sehingga berpengaruh juga terhadap nilai konsentrasinya.

\section{Ekstraksi DNA dengan Metode Ekstraksi Kit Purifikasi DNA Komersial dengan Menggunakan Reagen KIT QIAGEN (QIAamp® ${ }^{\circledR}$ DNA Investigator)}

Proses ekstraksi DNA dari sampel gigi dalam penelitian ini dilakukan dengan menggunakan metode ekstraksi kit purifikasi DNA komersial (Kit Qiagen (QIAamp® DNA Investigator)). Metode ini memiliki kelebihan dan kekurangan misalnya, metode kit purifikasi DNA komersial memiliki kelebihan diantaranya yaitu, cepat dan kuantitas DNA yang di hasilkan tinggi namun memiliki kekurangan terkait harga yang dikeluarkan cukup tinggi. Beberapa tahapan dalam metode ini ialah : pertama tahap lisis menggunakan buffer ATL dan Proteinase-K untuk memecah membran sel dan melepaskan DNA. Pengikatan DNA (DNA binding) menggunakan QIAamp MinElute Column dan buffer AL. Buffer AL mengandung asam guanidin untuk pengikatan terhadap column yang lebih kuat dan deterjen untuk merusak membran sel dengan merusak ion Mg2+ (integritas membran sel). Pemurnian DNA menggunakan buffer AW1 dan AW2, buffer AW1 mengandung stringent wash dengan konsentrasi guanidin yang rendah dan buffer AW2 mengandung Tris etanol untuk menghilangkan garam sebagai inhibitor pada proses PCR. Elusi DNA menggunakan ATE buffer yang merupakan tahapan terakhir. Dalam penelitian ini, dihasilkan DNA yang diperoleh dari hasil ekstraksi sampel gigi yang kemudian dilihat kuantitasnya mengunakan real-time PCR.

\section{Kuantifikasi DNA Menggunakan Real Time PCR}

Kuantitas DNA perlu diukur sebelum melanjutkan ke tahapan lebih lanjut dengan prosedur analisis untuk memastikan hasil yang optimal. Kantifikasi yang dilakukan pada penelitian ini menggunakan instrumen Real Time PCR HID 7500 Applied Biosystem. Kuantifikasi DNA merupakan

Hasil analisis pengaruh paparan fisik pada sampel gigi berupa paparan udara bebas, air sungai dan air laut dengan nilai konsentrasi DNA dalam penelitian ini menunjukkan tidak terdapat hubungan yang signifikan antar perlakuan. Hal ini dilihat dari besar nilai error bar pada masingmasing perlakuan, dimana sampel perlakuan paparan udara bebas pada suhu ruang yang diasumsikan sebagai sampel kontrol memiliki nilai error bar yang melingkupi nilai error bar dari sampel perlakuan perendaman dengan air sungai dan air laut. Sehingga besar variasi antar perlakuan juga kecil. Hasil analisis tersebut menunujukkan bahwa paparan fisik pada sampel gigi berupa paparan udara bebas, air sungai dan air laut tidak mempunyai pengaruh yang signifikan terhadap nilai konsentrasi DNA yang terdapat pada masing-masing sampel perlakuan. Sehingga, pemberian perlakuan pada sampel gigi berupa perendaman dengan air laut, perendaman dengan air sungai dan paparan udara bebas pada suhu ruang memiliki pengaruh yang tidak berbeda nyata.

Putri \& Yudianto (2016), menyatakan bahwa adanya penurunan kadar DNA menunjukkan adanya pengaruh lama waktu paparan, sehingga mengakibatkan adanya kerusakan struktur DNA. Kerusakan DNA yang disebabkan oleh paparanpaparan yang abnormal contohnya temperatur yang tinggi, disebabkan oleh rusaknya ikatan hidrogen DNA yang irreversible. Kondisi ini mengakibatkan kerusakan pasangan purinprimidin pada DNA, dimana pasangan purinprimidin ini merupakan komponen utama pada struktur DNA (Putri \& Yudianto, 2016).

\section{KESIMPULAN}

Berdasarkan penelitian yang telah dilakukan terkait Analisis Pengaruh Paparan Fisik pada Sampel Gigi Terhadap Hasil Kuantifikasi DNA Forensik dapat disimpulkan bahwa pengaruh 
paparan fisik berupa paparan udara bebas, paparan air sungai dan paparan air laut pada sampel gigi, tidak terdapat perbedaan yang nyata terhadap nilai konsentrasi DNA yang dihasilkan. Sehingga paparan fisik yang diberikan pada sampel tidak memberikan pengaruh yang signifikan dibuktikan dengan nilai rata-rata kosentrasi sampel pada masing-masing perlakuan yaitu perlakuan terpapar dengan udara bebas pada suhu ruang dengan nilai konsentrasi sebesar 1,34 $\mathrm{ng} / \mu \mathrm{l}$, perlakuan perendaman menggunakan air sungai dengan nilai konsentrasi sebesar 0,15 $\mathrm{ng} / \mu \mathrm{l}$, dan perlakuan perendaman air laut dengan nilai konsentrasi sebesar $0,10 \mathrm{ng} / \mu \mathrm{l}$.

\section{SARAN}

Penulis menyarankan agar dalam penelitian kedepannya bisa menambah variabel penelitian misalnya jenis paparan fisik pada sampel $(\mathrm{pH}$, salinitas, paparan limbah, dll) serta bisa dilakukan penelitian lanjutan terkait pengaruh perendaman sampel gigi terhadap ketebalan dentin gigi.

\section{DAFTAR PUSTAKA}

Bio-Rad Laboratories, 2017

Butler, J. M. 2010. Fundamental of Forensic DNA

Typing. USA: Elseiver Academic Press.

Butler, J.M. \& Hill. CR. 2012. Biology and genectic of new autosomal STR loci usefull for forensic DNA Analysis. Forensic Sci. Rev. 24(1):16-26.

Febri, K. Ardyni., Rahayu, P. Retno., dan Sosiawan., Agung. 2013. Analisis Heteroplasmy DNA Mitokondria Pulpa Gigi Pada Identifikasi Personal Forensik. Dental Journal, 46(3).

Hidayat, Rian. 2015. Perbandingan Metode Kit Komersial dan SDS Untuk Isolasi DNA Babi dan DNA Sapi pada Simulasi Cangkang Kapsul Keras Untuk Deteksi Kehalalan Menggunakan Real-Time PCR (Polimerase Chain Reaction). (Skripsi). Jakarta: UIN Syarif Hidayatullah Jakarta.

Higgins, Denice. \& Austin, Jeremy J. 2013. Teeth As A Source of DNA For Forensic Identification Of Human Remains. USA : Elseiver Academic Press.

Jehuda, Vandus. 2013. „Ekstraksi DNA dari Sperma pada Kondom dan Kain yang Tersimpan Sampai Dua Belas Hari : DNA Extraction From Sperm In The Condom And Fabrics That Were Stored Until Twelef Days'.
Jurnal Simbiosis I (1) :28- 39 ISSN : 23377224.

Latif, Muh. Talib Abd. 2012. Kelarutan Magnesium Email pada Perendaman Gigi dalam Minuman yang Mengandung Asam Bikarbonat dan Asam Sitrat ( In Vitro ). (Skripsi). Makassar : Universitas Hasanuddin Makassar.

Malaver, Piedad C., \& Yunis, Juan J. 2013. Different Dental Tissues as Source of DNA for Human Identification in Forensic Cases. Croatian Medical Journal, 44:306-309.

Mayall, Sandeep, Singh., Agarwal, Priyanka., \& Vashisth, Pallavi. 2013. Dental DNA Finger-Printing In Identification of Human Remains. Annals of Dental Speciality Journal, 01(01).

Prawestiningtyas, Eriko., \& Algozi, Agus, Mochammad. 2009. Identifikasi Forensik Berdasarkan Pemeriksaan Primer dan Sekunder Sebagai Penentu Identitas Korban pada Dua Kasus Bencana Massal. Jurnal Kedokteran Brawijaya, 25(2).

Putri, Ni Putu, P. Eka., \& Yudianto, Ahmad. 2016. Pengaruh Tanah dan Air Laut Terhadap Kualitas DNA dari Otot Psoas Jenazah Melalui Metode STR. Jurnal Biosains Pascasarjana, 18(3).

Sambrook, J., Russell, D. W. 2001. Molecular Cloning: A Laboratory Manual Third Edition. New York: Cold Spring Harbor Laboratory Press.

Syafitri, Kharlina., Auerkari, Elza., dan Suhartono, Winoto, 2013. Metode Pemeriksaan Jenis Kelamin Melalui Analisis Histologis dan DNA Dalam Identifikasi Odontology Forensik. Jurnal PDGI, 62(1), JanuariApril 2013, Hal. 11-16.

Tooy, C. David., Bernadus, B. Janno., dan Sorisi, Angle. 2016. Deteksi Plasmodium Falciparum Dengan Menggunakan Metode Real-Time Polymerase Chain Reaction Di Daerah Likupang Dan Bitung. (Skripsi). Manado : Universitas Sam Ratulangi Manado. 